\title{
A new species of the genus Scoliokona Kallies et Arita, 1998 (Lepidoptera: Sesiidae) from Bali, Indonesia with a catalogue of the genus
}

\section{Новый вид рода Scoliokona Kallies et Arita, 1998 (Lepidoptera: Sesiidae) с Бали, Индонезия с каталогом рода}

\author{
O.G. Gorbunov \\ О.Г. Горбунов
}

\begin{abstract}
A.N. Severtsov Institute of Ecology and Evolution, Russian Academy of Sciences, Leninsky prospekt 33, Moscow 119071, Russia. E-mail: gorbunov.oleg@mail.ru

Институт проблем экологии и эволюции им. А.Н. Северцова РАН, Ленинский проспект, 33, Москва 119071, Россия.
\end{abstract}

KEY WORDS. Lepidoptera, Paranthrenini, clearwing moths, Scoliokona, new species, Oriental Region, Indonesia.

КЛЮЧЕВЫЕ СЛОВА. Lepidoptera, Paranthrenini, бабочки-стеклянницы, Nokona, новый вид, Ориентальный регион, Индонезия.

ABSTRACT. A new species, Scoliokona baliensis sp.n. from the island of Bali, Indonesia, is described and figured. The holotype of the new species was collected with using artificial sex attractant. It is deposited in the collections of the A.N. Severtsov Institute of Ecology and Evolution of the Russian Academy of Sciences, Moscow, Russia. The female and the larval host plant are still unknown. This is the first record of the genus to the island of Bali. A new combination - Scoloikona stroehlei (Fischer, 2002), comb.n. is established.

РЕЗЮМЕ. Приведено описание нового вида, Scoliokona baliensis sp.n. с острова Бали, Индонезия. Голотип нового вида был собран с помощью искусственных половых аттрактантов. Он хранится в коллекции Института проблем экологии и эволюции им. А.Н. Северцова Российской академии наук в Москве. Это первое указание рода для острова Бали. Установлено новое сочетание - Scoloikona stroehlei (Fischer, 2002), comb.n.

\section{Introduction}

During a short-time trip to Indonesia in FebruaryMarch 2020, I could collect two very interesting species of Sesiidae. One of them was catch with the help of artificial sex attractants produced by PHEROBANK ${ }^{\circledR}$, Wijk bij Duurstede, the Netherlands. It was a representative of the genus Scoliokona Kallies et Arita, 1998. After a detailed study, it turned out to be a new species, the description of which is given below.
The genus Scoliokona was established for two species from the Philippines, one of which was described as a new [Kallies, Arita, 1998]. The authors selected Sura tetrapora Diakonoff, 1968 ["1967"] as the type species of the genus. It distributes in the Oriental region from Thailand and Myanmar in the west to the Philippines in the east, and from South China in the north to the island of Java in the south [Kallies, Arita, 1998; Arita, Riefenstahl, 2004; Pühringer, Kallies, 2004, 2021; Kallies et al., 2014; Yata et al., 2017]. The present finding shifts the range of the genus somewhat to the southeast.

Unfortunately, the exact systematic position of most species taxa of the subfamily Paranthreninae of the Oriental realm remains unclear. Practically most of them, with the exception of those newly described over the past couple of decades [Kallies, Arita, 1998; Arita, Gorbunov, 2001; Fischer, 2002, 2003; Arita et al., 2003; Kallies et al., 2014; Gorbunov, Arita, 2015, 2019; Gorbunov, 2016, 2018], remain insufficiently studied. This mainly concerns the structure of their genitalia. Very likely that most oriental species of the genus Paranthrene Hübner, 1819 ["1816"] (type species: Sphinx asyliformis [Denis et Schiffermüller], $1775=$ Sphinx tabaniformis Rottemburg, 1775) or Nokona Matsumura, 1931 (type species: Paranthrene (Nokona) yezonica Matsumura, 1931 = Sciapteron ferale Leech, 1889) should be transferred to the genus Scoliokona. Nevertheless, currently, I comprise only 14 species in this genus, including the new one described below.

The present paper presents the description of a new species, Scoliokona baliensis sp.n. In addition, I pro-

How to cite this article: Gorbunov O.G. 2021. A new species of the genus Scoliokona Kallies et Arita, 1998 (Lepidoptera: Sesiidae) from Bali, Indonesia // Russian Entomol. J. Vol.30. No.1. P.93-99. doi: 10.15298/ rusentj.30.1.11 
vide an annotated catalogue of the genus Scoliokona, which contains updated taxonomic information including references to the original descriptions, information on name-bearing types, complete bibliographies, data on host plants and distribution.

The holotype is described using a Leica EZ4 stereomicroscope with LED illuminations, and images is taken with a Sony ${ }^{\circledR} \alpha 450$ DSLR camera equipped with a Minolta $^{\circledR} 50 \mathrm{f} / 2.8$ Macro lens. The genitalia figures are taken with a Keyence ${ }^{\circledR}$ BZ-9000 Biorevo Fluorescence Microscope. The processing of all illustrations is finalized with the Adobe ${ }^{\circledR}$ Photoshop ${ }^{\circledR}$ CC 2020 software.

All labels of the holotype are cited verbatim. The labels of geographical data, imaging data and genitalia preparation numbers are printed on white paper, but the type label is printed on red paper. Each label is separated by a semicolon ";" lines in a label are separated by a slash "/". All pictures of the holotype are labeled with a number, consisting of letters and digits: name of the family, two consecutive digits separated by n-dash and a year following m-dash (e.g. SESIIDAE pictures №№ 0017-0018-2020). These letter and digit codes correspond to the numbering system of the figured specimens in the author's archive. The genitalia preparation is stored in a microtube with glycerol and pinned under the specimen. The dissected genitalia are equipped with the corresponding number placed in the microtube. This number as a label (e. g. genitalia preparation № OG001-2021) is pinned under the specimen and is listed in the archives of the author.
The material studied or mentioned below is kept in the following collections abbreviated in the text as follows:

BMNH - collection of the Natural History Museum, London, UK;

CHFR - private collection of Heinz Fischer, Rottach, Germany;

COGM - collection of the A.N. Severtsov Institute of Ecology and Evolution, Russian Academy of Sciences, Moscow, Russia;

ETHZ - Sammlung der Eidgenössische Technische Hochschule Zürich, Switzerland;

ITBC - collection of the Institute for Tropical Biology and Conservation, University of Malaysia, Sabah, Kota Kinabalu, Indonesia;

NSMT - collection of the National Museum of Nature and Science, Tsukuba, Tokyo (formerly Natural Science Museum Tokyo), Japan;

SCAU - collection of the Department of Entomology, South China Agricultural University, Guangzhou, Guangdong, China.

ZSM - Zoologische Staatssammlung München, Germany.

\section{Taxonomic account}

Scoliokona baliensis O. Gorbunov, sp.n. Figs $1-7$.

MATERIAL. Holotype $\sigma^{7}$ (Figs 2-3) with labels: "Indonesia, Bali, / Tabanan, Lalah Linggah, / 08²9.567’ S, 11458.287', / 50

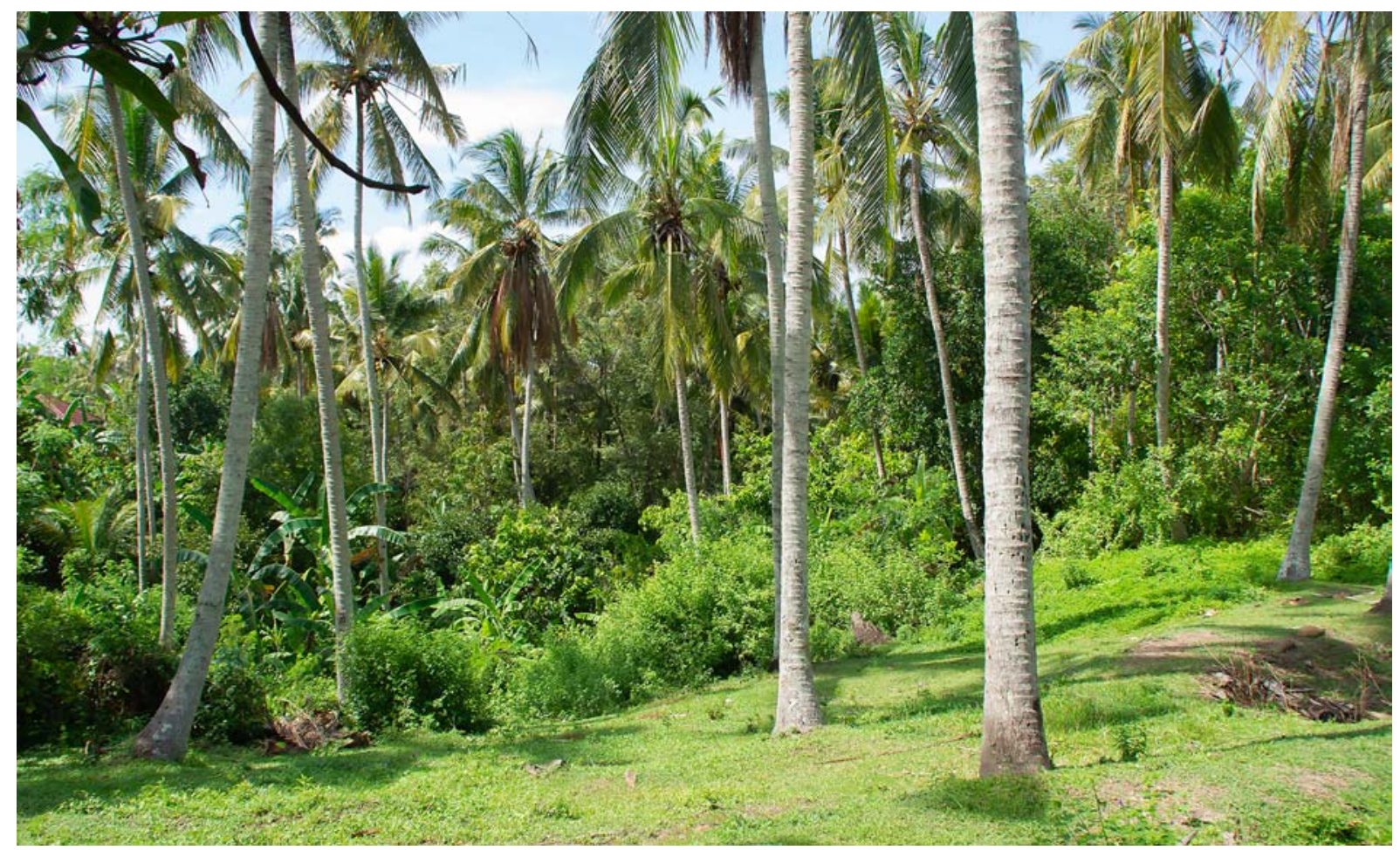

Fig. 1. Type locality of Scoliokona baliensis sp.n. Indonesia, Bali, Tabanan, Lalah Linggah, $08^{\circ} 29.567^{\prime}$ S, $114^{\circ} 58.287^{\prime}, 50$ m, 11.II.2020. Photo by O. Gorbunov.

Рис. 1. Типовое местонахождение Scoliokona baliensis sp.n. Индонезия, остров Бали, Табанан, Лалалингга, $08^{\circ} 29.567^{\prime} \mathrm{S}$, $114^{\circ} 58.287^{\prime}, 50$ м, 11.II.2020. Фото О. Горбунова. 


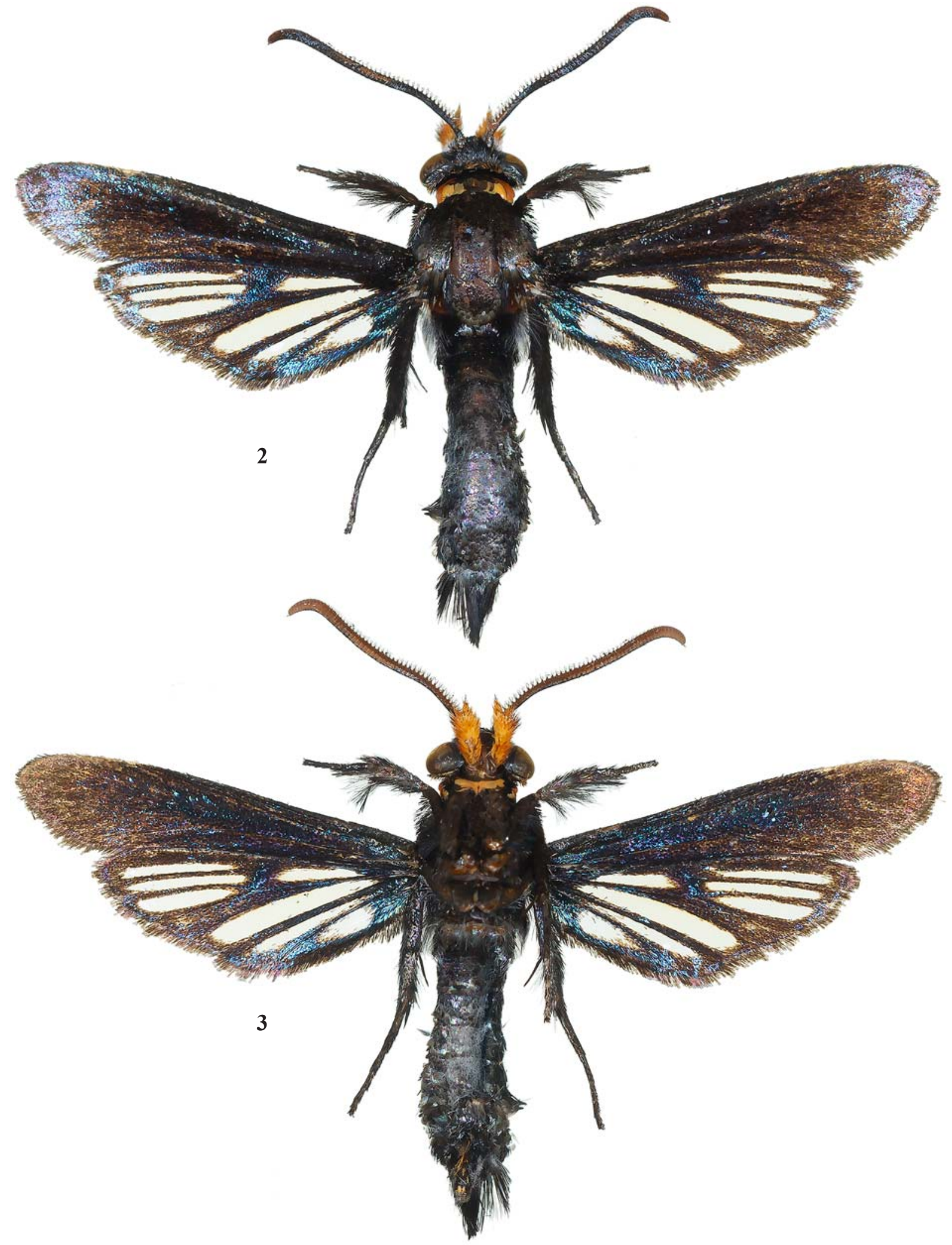

Figs 2-3. Scoliokona baliensis sp.n.: 2 - holotype, upside. Sesiidae picture № 0017-2020. Alar expanse 32.8 mm; 3 - ditto underside. Sesiidae picture № 0018-2020.

Рис. 2-3. Scoliokona baliensis sp.n.: 2 - голотип, сверху. Sesiidae снимок № 0017-2020. Размах крыльев 32,8 мм; 3 - снизу. Sesiidae снимок № 0018-2020. 
m, 11.II.2020, / O. Gorbunov leg." (white); "SESIIDAE / Pictures №№ / 0017-0018-2020 / Photo by O. Gorbunov" (white); "Genitalia examined / by O. Gorbunov / Preparation № / OG-001-2021' (white); "HOLOTYPUS $\sigma^{7} /$ Scoliokona baliensis / O. Gorbunov, 2020 / O. Gorbunov des., 2020" (red) (COGM).

DESCRIPTION. Male (holotype) (Figs 2-3). Alar expanse $32.8 \mathrm{~mm}$; body length $19.1 \mathrm{~mm}$; forewing $15.0 \mathrm{~mm}$; antenna $8.0 \mathrm{~mm}$.

Head with antenna black with dark blue-violet sheen dorsally and dark brown ventrally; scapus dark gray-brown with greenish-blue sheen and a few yellowish scales laterally; frons dark brown with bright greenish-violet sheen and a very narrow gray stripe laterally; labial palpus orange with a few thin, elongate, black scales both externally and dorsally on mid joint; vertex black with anthracite sheen; pericephalic hairs orange with an admixture of black hair-like scales dorsally.
Thorax with patagia orange with an admixture of a few black scales with greenish-violet sheen dorsally; tegula, mesoand metathorax and thorax laterally entirely black with bright greenish-violet sheen; posteriorly dark gray with greenishbronze sheen covered with long white hair-like scales. Legs with neck plate orange with a few black scales with greenish sheen laterally; fore, mid and hind legs entirely black with violet-anthracitic sheen; both fore femur and fore tibia posteriorly with elongate hair-like scales forming a well-visible tuft; spurs mid and hind tibiae dark gray with anthracitic sheen internally. Forewing completely opaque; dorsally black with bright blue-violet sheen; cilia dark brown to black with dark violet sheen; ventrally dark brown to black with bright blue sheen gradually changing to violet distally of cross-vein; cilia dark brown to black with bronze-violet sheen. Hindwing with scales black with bright blue sheen dorsally and blueviolet sheen ventrally; with seven oval transparent areas in

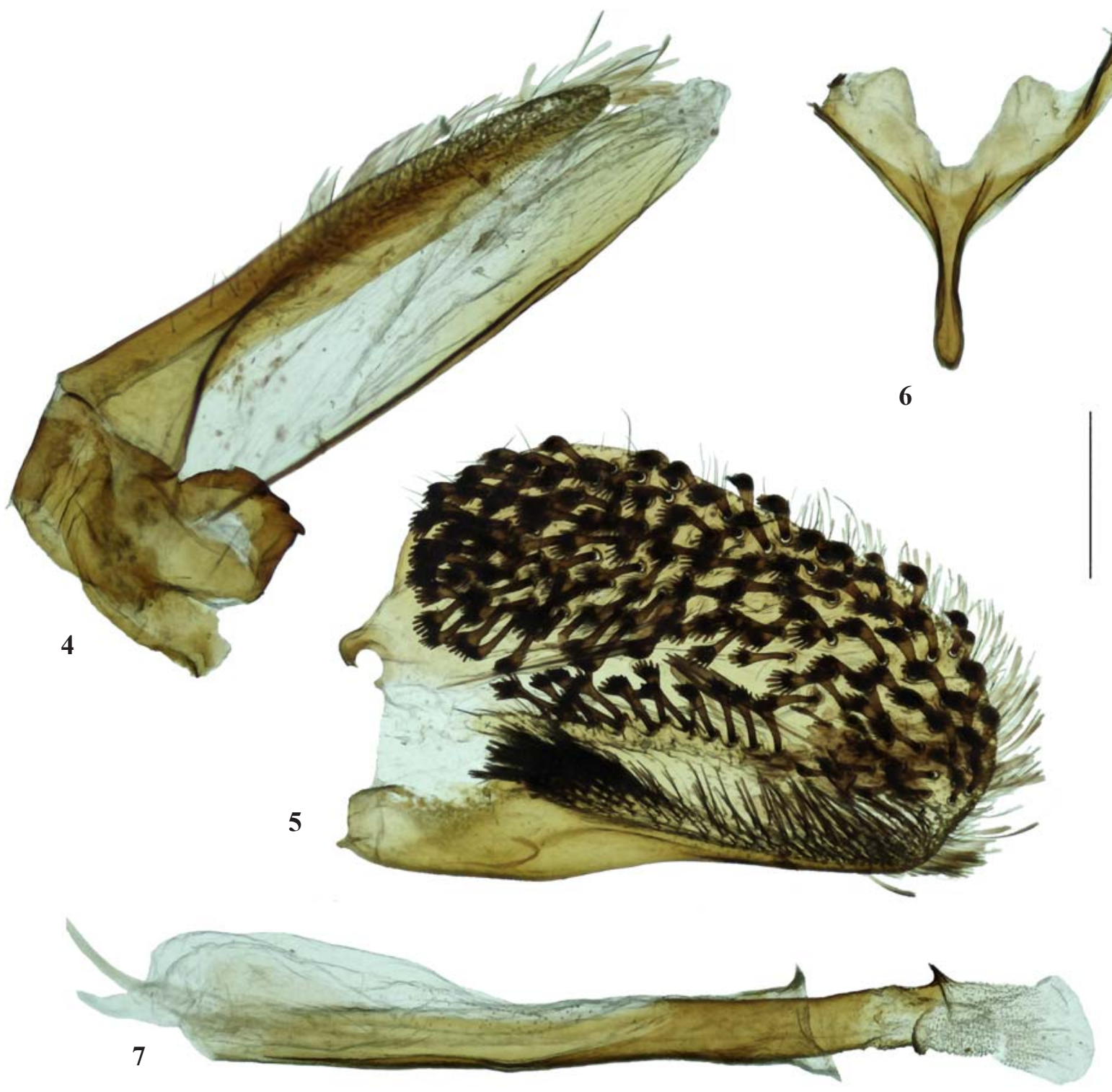

Figs 4-7. Male genitalia of Scoliokona baliensis sp.n., holotype. Genital preparation № OG-001-2021: 4 — tegumen-uncus complex; 5 - valva; 6 - saccus; 7 - aedeagus. Scale bar: $0.5 \mathrm{~mm}$.

Рис. 4-7. Гениталии самца Scoliokona baliensis sp.n., голотип. Препарат гениталий № OG-001-2021: 4 - тегумен-ункус комплекс; 5 - вальва; 6 - саккус; 7 - эдеагус. Масштаб: 0,5 мм. 
cell proximally of discal spot, distally of discal spot between veins $\mathrm{M}_{1}-\mathrm{CuA}_{1}$ and $\mathrm{CuA}_{2}$-anal margin; cilia dark brown to black with dark violet sheen dorsally and bronze-violet sheen ventrally.

Abdomen entirely black with bright blue-violet sheen; anal tuft with a few white with yellowish tint scales laterally.

Male genitalia (holotype) (genital preparation № $\mathrm{OG}-$ 001-2021) (Figs 4-7). Uncus long, narrow, slightly broadened medially, with simple setae laterally; tegumen short; gnathos narrow, with triple tooth; tuba analis with subscaphium narrowly sclerotized (Fig. 4); valva (Fig. 5) valva broad, ovoid and relatively short, with dorsal half covered with strong hand-shaped setae, a row of such setae medially and a stripe of pointed setae subventrally; crista sacculi low, with a patch of strong pointed setae; saccus (Fig. 6) slightly shorter than vinculum, straight, narrow, somewhat broadened and rounded basally; aedeagus (Fig. 7) rather broad, somewhat longer than valva, distally with a hook-shaped well-sclerotized carina penis dorsally and a sclerotized plate ventrally; vesica with numerous rows of minute flat cornuti.

Female. Unknown.

INDIVIDUAL VARIABILITY. Unknown.

DIFFERENTIAL DIAGNOSIS. By the conformation of the hindwing this new species is somewhat similar to $S$. kalliesi Arita et Riefenstahl, 2004, but it differs by the colouration of the antenna (antenna orange in $S$. kalliesi), by the presence of transparent areas between veins $M_{1}$ and $M_{2}$ and $\mathrm{CuP}$ and 1A of the hindwing [all these cells opaque in $S$. kalliesi; compare Fig. 2 with fig. 1 in Arita, Riefenstahl, 2004: 117], and by the structure of the male genitalia, especially by the shape of the gnathos (with double tooth in the species compared) and valva [compare Figs 4-7 with fig. 2 in Arita, Riefenstahl, 2004: 117]. From all other congeners this new species is clearly distinguishable by the orange patagia, structure of the transparent cells of the hindwing and by te conformation of the male genitalia.

BIONOMICS. The larval host plant is unknown. The holotype was collected in early February with help of unspecific artificial sex pheromones. At least four specimens were attracted from which, unfortunately, only one was collected. They came to the lures from about 7.30 am to 10 am local time.

HABITAT. The holotype was collected at the edge of a coconut plantation and a secondary rainforest (Fig. 1).

DISTRIBUTION. The new species is known only from the type locality on the island of Bali, Indonesia.

ETHYMOLOGY. This new species is named after the island Bali, Indonesia, where this species was collected.

\section{Catalogue of the genus Scoliokona Kallies} et Arita, 1998

\section{Scoliokona Kallies et Arita, 1998}

"Scoliokona gen. nov." -Kallies, Arita, 1998: 259. Type species: Sura tetrapora Diakonoff, 1968 ["1967"], by original designation.

LITERATURE. Pühringer, Kallies, 2004: 19 (Scoliokona); Kallies et al., 2014: 185, 186, 194 (Scoliokona); Pühringer, Kallies, 2021 (Scoliokona).

HOST PLANTS. Uncaria gambir (Hunter) Roxb. (Rubiaceae) is known as a host plant for $S$. cyanogama and $S$. uncariae. Highly likely, the same plant could be a larval host for S. cyanea [Schnaider, 1940: 41].

RANGE. Oriental realm from Thailand and Myanmar in the west to the Philippines in the east, and from South China in the north to the Indonesian island of Bali in the south.

\section{Scoliokona baliensis O. Gorbunov, sp.n.}

"Scoliokona baliensis sp.n." - present publication, Figs 1-7. Type locality: Indonesia, Bali, Tabanan, Lalah Linggah. Holotype $\sigma^{\top}$ (COGM). FLIGHT PERIOD. The holotype was collected in February. HOST PLANT. Unknown.

DISTRIBUTION. It is known from the islands of Bali, Indonesia.

Scoliokona cyanea (Hampson, 1919)

"Sura cyanea n. sp." - Hampson, 1919: 99. Type locality: "Java, Arjuno ..." [= Indonesia: East Java, Arjuno-Welirang]. Holotype $\sigma^{\top}(\mathrm{BMNH})$.

LITERATURE. Dalla Torre, Strand, 1925: 151 (Sura cyanea); Gaede, 1933: 792 (Sura cyanea); Schnaider, 1940: 41 (Sura cyanea); Heppner, Duckworth, 1981: 25 (Sura cyanea); Pühringer, Kallies, 2004: 19 (Scoliokona cyanea); Kallies et al., 2014: 194 (Scoliokona cyanea); Pühringer, Kallies, 2021 (Scoliokona cyanea).

FLIGHT PERIOD. Unknown.

HOST PLANT. Unknown.

DISTRIBUTION. This species is known as a single male (holotype) from the island of Java, Indonesia.

\section{Scoliokona cyanogama (Meyrick, 1930)}

"Paranthrene cyanogama, n. sp." - Meyrick, 1930: 584. Type locality: "Malaya, Johore, ..." [Malaysia: Johor]. Syntypes $1 \sigma^{7}$ and 1 ㅇ (BMNH).

LITERATURE. Gaede, 1933: 794 (Paranthrene cyanogama); Yunus, Ho, 1980: 61, 440, 441 (Paranthrene cyanogama); Heppner, Duckworth, 1981: 23 (Paranthrene cyanogama); Kalshoven, 1981: 213 (Paranthrene cyanogama); Robinson et al., 1994: 109, pl. 18, fig. 6 (Paranthrene cyanogama); Robinson et al., 2001: 308, 632 (Paranthrene cyanogama); Pühringer, Kallies, 2004: 20 (Paranthrene cyanogama); Kallies et al., 2014: 194, 195 (Scoliokona cyanogama); Pühringer, Kallies, 2021 (Paranthrene cyanogama).

FLIGHT PERIOD. The specimens of the type series were bred in January.

HOST PLANT. Larvae boring stems of Uncaria gambir (Rubiaceae)

DISTRIBUTION. Known from the state of Johor in South Malaysia.

\section{Scoliokona heptapora Kallies et Arita, 1998}

"Scoliokona heptapora sp. nov." - Kallies, Arita, 1998: 264, figs 15, 26a-d. Type locality: "Philippinen, Leyte, Lake Danao, 650 $\mathrm{m}$, ...”. Holotype $\sigma^{\top}$ (ZMHU).

LITERATURE. Arita et al., 2003: 140 (Scoliokona heptapora); Arita, Riefenstahl, 2004: 116 (Scoliokona heptapora); Pühringer, Kallies, 2004: 19 (Scoliokona heptapora); Kallies et al., 2014: 201 (Scoliokona heptapora); Pühringer, Kallies, 2021 (Scoliokona heptapora);

FLIGHT PERIOD. The type series was collected in April. HOST PLANT. Unknown.

DISTRIBUTION. It is known from the islands of Leyte and Samar in the Philippines.

\section{Scoliokona hyalina Arita et O. Gorbunov, 2003}

"Scoliokona hyalina Arita \& Gorbunov sp. nov." - Arita et al., 2003: 138, figs 3, 8a-d. Type locality: “ ... Malaysia, Sabah, Maliau Basin, Agathis Camp, ...". Holotype ơ (ITBC).

LITERATURE. Arita, Riefenstahl, 2004: 116 (Scoliokona hyalina); Pühringer, Kallies, 2004: 19 (Scoliokona hyalina); Pühringer, Kallies, 2021 (Scoliokona hyalina).

FLIGHT PERIOD. The type series was collected in May. HOST PLANT. Unknown.

DISTRIBUTION. Known from the island of Borneo. 
Scoliokona kalliesi Arita et Riefenstahl, 2004

"Scoliokona kalliesi sp. nov." - Arita, Riefenstahl, 2004: 116, figs 1, 2. Type locality: “... Myanmar, Kachin, Putao, Mt. New Zin, ...". Holotype $\sigma^{7}$ (NSMT).

LITERATURE. Pühringer, Kallies, 2004: 19 (Scoliokona kalliesi); Kallies et al., 2014: 200 (Scoliokona kalliesi); Yata et al., 2017: 22, figs 1-5 (Scoliokona kalliesi); Pühringer, Kallies, 2021 (Scoliokona kalliesi).

FLIGHT PERIOD. The type series was collected in April and June.

HOST PLANT. Unknown.

DISTRIBUTION. This species is known from Myanmar, Thailand and Vietnam.

Scoliokona nanlingensis Kallies et Arita, 2014

"Scoliokona nanlingensis Kallies \& Arita sp. nov." — Kallies et al., 2014: 195, figs 21, 22, 36. Type locality: “... Prov. Guandong [sic!], Shaoguang, Nanling, $800 \mathrm{~m}, \ldots$... [= China: Guangdong Province, Shaoguang, Nanling Mountains]. Holotype $\sigma^{7}$ (SCAU).

LITERATURE. Pühringer, Kallies, 2021 (Scoliokona nanlingensis).

FLIGHT PERIOD. The type series was collected in August and September.

HOST PLANT. Unknown.

DISTRIBUTION. Known from Guangdong Province in South China.

Scoliokona phoenicia (Hampson, 1919)

"Sura phoenicia n. sp." - Hampson, 1919: 99. Type locality: "Borneo, Pulo Laut ..." [= Indonesia: Kalimantan Selatan, Pulau Laut]. Holotype + (BMNH).

LITERATURE. Dalla Torre, Strand, 1925: 151 (Sura phoenicia); Gaede, 1933: 792 (Sura phoenicia); Heppner, Duckworth, 1981: 25 (Sura phoenicia); Kallies, Arita, 1998: 263 (Sura phoenicia); Pühringer, Kallies, 2004: 22 (Sura phoenicia); Kallies et al., 2014: 194 (Scoliokona phoenicia); Pühringer, Kallies, 2021 (Scoliokona phoenicia).

FLIGHT PERIOD. The holotype was collected in June. HOST PLANT. Unknown.

DISTRIBUTION. This species is known from the island of Laut in Indonesia.

\section{Scoliokona shimentai Kallies et Wu, 2014}

"Scoliokona shimentai Kallies \& Wu sp. nov." - Kallies et al., 2014: 195, figs 23, 24, 37. Type locality: “... Prov. Guangdong, Yingde, Shimentai, ..." [= China: Guangdong Province, Yingde, Shimentai Nature Reserve]. Holotype $\sigma^{7}$ (SCAU).

LITERATURE. Kallies et al., 2014: 201 (Scoliokona shimentai); Yata et al., 2017: 22 (Scoliokona shimentai); Pühringer, Kallies, 2021 (Scoliokona shimentai).

FLIGHT PERIOD. The type series was collected from late April to early July.

HOST PLANT. Unknown.

DISTRIBUTION. It is known from Guangdong Province in South China and from the provinces of Th a Thiên-Hu and Cao B ng in Vietnam.

Scoliokona spissa Kallies et Arita, 2014

"Scoliokona spissa Kallies \& Arita sp. nov." - Kallies et al., 2014: 200, figs 25, 26, 38. Type locality: “... Guangxi, Guilin, Maoershan, ...” [= China: Guangxi Zhuang Autonomous Region, Guilin, Mao'er Mountains]. Holotype $\sigma^{7}$ (SCAU).

LITERATURE. Pühringer, Kallies, 2021 (Scoliokona spissa).

FLIGHT PERIOD. The type series was collected in July and August.

HOST PLANT. Unknown.
DISTRIBUTION. Known from Guangdong Province and Guangxi Zhuang Autonomous Region in South China.

Scoloikona stroehlei (Fischer, 2002), comb.n.

"Nokona stroehlei sp. nov." - Fischer, 2002: 141, Abb. 1-10. Type locality: "Malaysische Halbinsel, Cameron Highlands, SW Ringlet, $04^{\circ} 21^{\prime} 16^{\prime \prime} \mathrm{N}, 101^{\circ} 20^{\prime} 17^{\prime \prime}, 550 \mathrm{~m}, . . . "$ [= Malaysia: Pahang, Cameron Highlands, environs of Ringlet]. Holotype $\sigma^{\top}$ (CHFR, later in ZSM).

LITERATURE. Pühringer, Kallies, 2004: 18 (Nokona stroehlei); Pühringer, Kallies, 2021 (Nokona stroehlei). July.

FLIGHT PERIOD. The holotype was collected in mid-

\section{HOST PLANT. Unknown.}

DISTRIBUTION. Known from the type locality in Malaysia only.

\section{Scoliokona tetrapora (Diakonoff, 1968 [“1967”])}

"Sura tetrapora, new species" — Diakonoff, 1968: 228, figs $345,713,714$. Type material: “... Luzon, Prov. Limay, Bataan, ...” [= the Filippines: Central Luzon region, province Bataan, Limay]. Holotype + (USNM).

LITERATURE. Heppner, Duckworth, 1981: 25 (Sura tetrapora); Kallies, Arita, 1998: 261, 266, figs 13, 14, 24, 25, 31 (Scoliokona tetrapora); Arita et al., 2003: 140 (Scoliokona tetrapora); Arita, Riefenstahl, 2004: 116 (Scoliokona tetrapora); Pühringer, Kallies, 2004: 19 (Scoliokona tetrapora); Kallies et al., 2014: 201 (Scoliokona tetrapora); Pühringer, Kallies, 2021 (Scoliokona tetrapora).

FLIGHT PERIOD. The imago occurs in April and in November.

HOST PLANT. Unknown.

DISTRIBUTION. This species is known from the islands of Luzon and Mindanao in the Philippines.

\section{Scoliokona uncariae (F. Schneider, 1940)}

"Sura uncariae sp. nov." - Schneider, 1940: 116, 205, Abb. 15, 42. Type locality: "[Sumatra, ... zwischen dem 2. und 3. nördlichen Breitegrad, etwa $50 \mathrm{~km}$ landeinwärts an der flachansteigenden Ostküste in 25-40 m Höhe über Meer ... ]" [= Indonesia: Sumatra, North Sumatra, Asahan Regency]. Holotype $q$ missing (not in ETHZ).

LITERATURE. Heppner, Duckworth, 1981: 25 (Sura uncariae); Kalshoven, 1981: 213, fig. 175 (Sura uncariae); Kallies, Arita, 1998: 263 (Sura uncariae); Robinson et al., 2001: 391, 632 (Sura uncariae); Pühringer, Kallies, 2004: 22 (Sura uncariae); Kallies et al., 2014: 194 (Scoliokona uncariae); Pühringer, Kallies, 2021 (Scoliokona uncariae).

FLIGHT PERIOD. Unknown.

HOST PLANT. Larvae boring trunks or large branches of Uncaria gambir (Rubiaceae).

DISTRIBUTION. Known from the island of Sumatra, Indonesia.

\section{Scoliokona zygophora (Hampson, 1919)}

"Paranthrene zygophora n. sp." - Hampson, 1919: 109. Type locality: "Borneo, Sarawak, Kuching ..." [= Malaysia: Sarawak, Kuching]. Holotype $q$ (BMNH).

LITERATURE. Dalla Torre, Strand, 1925: 169 (Paranthrene zygophora); Gaede, 1933: 795 (Paranthrene zygophora); Heppner, Duckworth, 1981: 24 (Paranthrene zygophora); Pühringer, Kallies, 2004: 21 (Paranthrene zygophora); Kallies et al., 2014: 194, 195 (Scoliokona zygophora); Pühringer, Kallies, 2021 (Scoliokona zygophora).

* According to Clarke [1980], the actual date of publication of the 257 issue of the Bulletin of the United States National Museum is January 31 st, 1968 ("1868" in the text!). 
FLIGHT PERIOD. The holotype was collected in January. HOST PLANT. Unknown.

DISTRIBUTION. This species is known from the Sarawak Province of Borneo, Indonesia.

Acknowledgements. I would like to express my cordial thanks to Mr. Andrei A. Zagorinskiy, Prof. Dmitry G. Zamolodchikov and Dr. Vasily K. Tuzov (all from Moscow, Russia) for the company and help during our successful trip to Indonesia in 2020. I am indebted to Mr. Vlad Proklov (London, England) for carefully checking the English of an advanced draft.

The study was conducted using the equipment of the Joint Usage Center "Instrumental methods in ecology" at the A.N. Severtsov Institute of Ecology and Evolution, Russian Academy of Sciences (Moscow, Russia).

\section{References}

Arita Y., Gorbunov O.G. 2001. Sesiidae of Taiwan. I. The tribes Tinthiini, Similipepsini, Paraglosseciini, Pennisetiini, Paranthrenini and Cissuvorini // Jpn. J. syst. Ent. Vol.7. No.2. P. 131-188.

Arita Y., Gorbunov O.G., Mohamed M. 2003. On the knowledge of the clearwing moths (Lepidoptera, Sesiidae) of the Mliau Basin, Sabah, Borneo // Trans. Lepid. Soc. Jpn. Vol.54. No.2. P.131142.

Arita Y., Riefenstahl H. 2004. A new Scoliokona Kallies \& Arita 1988 (Lepidoptera: Sesiidae, Paranthrenini) from south-east Asia, with list of literature on oriental Sesiidae published since 1988 // Ent. Zeit. Bd.114. Nr.3. S.116-120.

Clarke J.F.G. 1980. Transfer of Microlepidoptera types to the Smithsonian Institution // Proc. Ent. soc. Washington. Vol.82. No.4 P.540.

Dalla Torre K.W., Strand E. 1925. Aegeriidae // Strand E. (Hrsg.). Lepidopterorum Catalogus. Bd.31. Berlin: W. Junk. 202 S.

Diakonoff A.N. 1968. Microlepidoptera of the Philippine Islands // U.S. Nat. Mus. Bull. No.257. P.1-484.

Fischer H. 2002. Nokona stroehlei sp. nov., eine neue Glasflüglerart aus den Cameron Highlands in Malaysia (Lepidoptera: Sesiidae, Sesiinae) // Ent. Z. Bd.112. Nr.5. S.141-143.

Fischer H. 2003. Nokona christineae sp. nov., eine neue Glasflüglerart aus den Cameron Highlands in Malaysia (Lepidoptera: Sesiidae, Sesiinae) // Ent. Z. Bd.113. Nr.5. S.139-141.

Gaede M. 1933. Family Aegeriidae // Seitz A. (Hrsg.). Die GrossSchmetterlinge der Erde: eine systematische Bearbeitung der bis jetzt bekannten Gross-Schmetterlinge. II. Abteilung - Exotische Fauna. Bd.10. Die Indo-Australischen Spinner und Schwärmer. Stuttgart: A.Kernen Verlag. S.777-802. Taf.94-95.

Gorbunov O.G. 2016. Nokona mahawu sp. n., a new clearwing moth species (Lepidoptera, Sesiidae) from North Sulawesi, Indonesia // Russian Entomol. J. Vol.25. No.2. P.161-165.
Gorbunov O.G. 2018. A new species of the genus Taikona Arita et O. Gorbunov, 2001 from the Malay Peninsula (Lepidoptera, Sesiidae) // Russian Entomol. J. Vol.27. No.3. P.293-296.

Gorbunov O.G., Arita Y. 2015. A new species of the genus Nokona Matsumura, 1931 (Lepidoptera, Sesiidae) from South Sulawesi // Far Eastern Entomologist. No.293. P.1-6.

Gorbunov O.G., Arita Y. 2019. A new species of the genus Taikona O. Gorbunov \& Arita, 2001 from Vietnam (Lepidoptera: Sesiidae) // Zootaxa Vol.4624. No.1. P.137-141.

Hampson G.F. 1919. A classification of the Aegeriadae [sic] of the Oriental and Ethiopian Regions // Novitates Zoologicae. Vol.26. No.1. P.46-119.

Heppner J.B., Duckworth W.D. 1981. Classification of the Superfamily Sesioidea (Lepidoptera, Ditrysia) // Smithsonian Contr. Zool. Vol.314. P.1-144.

Kallies A., Arita Y. 1998. New and little known clearwing moths (Lepidoptera, Sesiidae) from the Philippine Islands // Trans. Lepid. Soc. Jpn. Vol.49. No.4. P.245-270.

Kallies A., Arita Y., Owada M., Wu G.-Y., Wang M. 2014. The Paranthrenini of Mainland China (Lepidoptera, Sesiidae) // Zootaxa. Vol.3811.No.2. P.185-206.

Kalshoven L.G.E. 1981. The pests of crops in Indonesia. Translated and revised by P.A. van der Laan. Jakarta: P.T. Ichtiar Baru. XIX $+701 \mathrm{pp}$.

Meyrick E. 1930. Aegeriadae [sic!]. Exotic Microlepidoptera. Vol.3. P.584-585.

Pühringer F., Kallies A. 2004. Provisional checklist of the Sesiidae of the world (Lepidoptera: Ditrysia) // Mitt. Ent. Arb. gem. Salzkammergut. Bd.4. S.1-85.

Pühringer F., Kallies A. 2021. Checklist of the Sesiidae of the world (Lepidoptera: Ditrysia). Online database. Last modified: 19.11.2020. Available from: http://www.sesiidae.net/ (accessed 04 February 2021)

Robinson G.R., Ackery P.R., Kitching I.J., Beccaloti G.W., Hernández L.M. 2001. Hostplants of the moth and butterfly caterpillars of the Oriental Region. London: Natural History Museum. 744 pp.

Robinson G.S., Tuck K.R., Shaffer M. 1994. A field guide to the smaller moths of South-East Asia. Kuala Lumpur: Malaysian Nature Society. 309 pp

Robinson G.S., Ackery P.R., Kitching I.J., Beccaloni G.W., Hernández L.M. 2001. Hostplants of the moth and butterfly caterpillars of the Oriental Region. London: the Natural History Museum. $744 \mathrm{pp}$.

Schneider F. 1940. Schadinsekten und ihre Bekämpfung in ostindischen Gambirkulturen // Mitt. Schweiz. Ent. Ges. Bd.18. No.3. S.77-207.

Yata N., Onodera S., Ogane H., Toda N., Arita Y. 2017. A new record of clearwing moths of the genus Scoliokona (Lepidoptera, Sesiidae) from northern Vietnam // Tinea. Vol.24. No.1. P.2223.

Yunus A., Ho T.H. 1980. List of economic pests, host plants, parasites and predators in West Malaysia (1920-1978) // Bull. Malaysian Department Agricult. No.153. III + 538 pp. 